\title{
Analysis of Building Passive Design Strategies in Solar Decathlon China 2013
}

\author{
Feng SHI \\ School of Architecture and Civil Engineering \\ Xiamen University \\ Xiamen, China \\ e-mail: Shifengx@126.com \\ Tao ZHUANG \\ School of Architecture and Civil Engineering \\ Xiamen University \\ Xiamen, China \\ e-mail: 1243618593@qq.com
}

\author{
Wei JIN \\ School of Architecture and Civil Engineering \\ Xiamen University \\ Xiamen, China \\ e-mail: 253454565@qq.com \\ Weiwei ZHENG \\ School of Architecture and Civil Engineering \\ Xiamen University \\ Xiamen, China \\ e-mail: 84380583@qq.com
}

\begin{abstract}
Thermal environment regulation strategy is the key point to creating a comfortable building environment and important in building energy efficiency. This paper takes the zero-energy buildings in Solar Decathlon China (SDC2013) competition as examples, to analyze the thermal environment regulation strategies in solar houses and sort them out according to their technical characteristics. The no-energyconsuming passive solar technologies such as shading, natural ventilation, energy storage, evaporation cooling, etc, are analyzed in the paper and their application in SDC2013 have been discussed to provide references for contemporary green building design.
\end{abstract}

Keywords-building thermal environment; regulation strategy; Solar Decathlon China; solar house; passive solar technology

\section{INTRODUCTION TO SOLAR DECATHLON CHINA}

The international solar decathlon competition (Solar Decathlon) is a solar building technology competition for global universities which is called "The Olympic Games in the field of solar building", and is launched and host by the U.S. department of energy. It challenges collegiate teams to design, build and operate solar-powered houses that are comfortable, livable and sustainable living spaces. Solar energy is the only energy source of each house with an area of about 80 square meters. These solar houses must meet the requirements of the various functions of residence and be operated actually for test contests. Five sessions of the competition are hosted in the United States (SDA2002 SDA2005, SDA2007, SDA2009, SDA2011), two sessions in Spain (SDE2010, SDE2012), and in August 2013, one session in China for the first time (SDC2013). SDC2013's participants include 20 teams from 35 universities with students from over 35 nationalities in 13 countries on 6 continents, which reflect that China attaches great importance to the application and promotion of new energy, and performs the action of building energy conservation and emissions reduction, and also greatly expands the influence of the competition [1].
Zero energy solar houses exhibited in SD reflect different universities' progress in the field of building energy conservation and solar energy application [2]. In the contests indoor air temperature, air humidity were measured during the schedule time in the competition, and HVAC system design, ventilation design, and air quality were also evaluated by experts, which occupied one fifth of the total score of the competition. Therefore, thermal environment regulation strategy was one of the key points for each team in their solar house design. In SDC2013, various innovative strategies can be seen in the houses in order to meet the requirements of thermal comfort and save energy at the same time.

\section{PASSive Design StRategies}

In order to meet the requirements of zero energy consumption, on the one hand, energy should be produced as much as possible through reasonable photovoltaic design; on the other hand, it is necessary that we can reduce energy consumption as far as possible by the energy saving design. Among these methods, using the passive design strategies to regulate thermal environment of building which can achieve the requirements of the comfort without energy and can reduce the working time of active devices to get the best energy-saving effect is a very important part of building zero-energy design .Passive design strategies for building thermal environment regulation mainly includes shading, natural ventilation, energy storage, evaporative cooling, etc., and the comprehensive application of design strategies on the basis of above methods.

\section{Sunshade Design}

The competition site of SD is always chosen in place that has a lot of solar energy because of what solar radiation strength will be very high during the competition. In order to meet the requirements of temperature and humidity the design of sunshade becomes one of the important factors. Houses built by many teams in Solar Decathlon take sunshade design seriously. And sunshade device which can 
be regulated to keep the sunshine in or out of the house according to the change of weather outdoor, which is an effective strategy to regulate building thermal environment [3].

\section{A. Sunshade of Doors and Windows}

Abat vent of door and window and sun louver are the basest methods of regulation sunshade type. There are many types of sunshade in the competition, such as inside abat vent, outside sun louver, sun louver in cavity of glasses and so on. Inside sunshade system is mostly connected to building intelligent control system for automatic controlling. In Xiamen University's house "Sunny Inside", the inside abat vent can be turned on or off according to the room illumine by intelligent control system. Sun louver in cavity of glasses can integrate doors and windows with sunshade, which has an attractive appearance and is easy to be cleaned. Harbin Institute of Technology's house "Nexus House" adopts woodenness outside sun louver (Fig.1). Roller shutter system is popular in skylight sunshade. "Sunny Inside" uses roller shutter in courtyard skylight sunshade system and shutter motor is chosen in the use of waterproof tubular motor whose weather fastness is very well. There is a $30 \mathrm{~cm}$ cavity between roller shutters and skylight glasses advantageous to the ventilation and heat dissipation and not affect open of skylight.

\section{B. Architectural Shading System}

Architectural shading system takes advantage of veranda, framework, cornice and other building components for the function of shading and creates a transition space from indoor to outdoor. Architectural shading system is widely used in Solar Decathlon. For example, Xi'an University of Architecture and Technology's house "Qi Ju" sets a wide south loggia which is a semi-outdoor space that can be used as the platform of outdoor activities. The loggia uses a glass ceiling with white opaque rolling bead curtain inside for summer shading. In winter the abat vent can be closed, and then, loggia can be used as passive solar greenhouse which will improve indoor thermal environment indirectly. (Fig.2)

Chalmers University of Technology from Sweden design a circular model for their house "HALO" providing an organic public space with a nice outdoor habitable space beneath the north and south eaves which is a transition space from indoor to outdoor. The building integrates photovoltaic with the roof design. Roofing materials use $82 \mathrm{~m}^{2}$ polycarbonate film integrated with $10 \mathrm{~kW}$ single crystalline silicon solar module installed on glulam arch which is made in Sweden. Solar roof can keep out the sunshine for the building and the outdoor platform and meet the various requirements with the changing solar altitude. (Fig.3) Tsinghua University's house "O-house" sets $1 \mathrm{Kw}$ photovoltaic sun louver at the south corridor, which can adjust the shutter orientation angle as needed. In transition season and summer night corridor will be fully open to nature for cooling and ventilation. And corridor becomes indoor space with sun louver closed in winter for preheating.

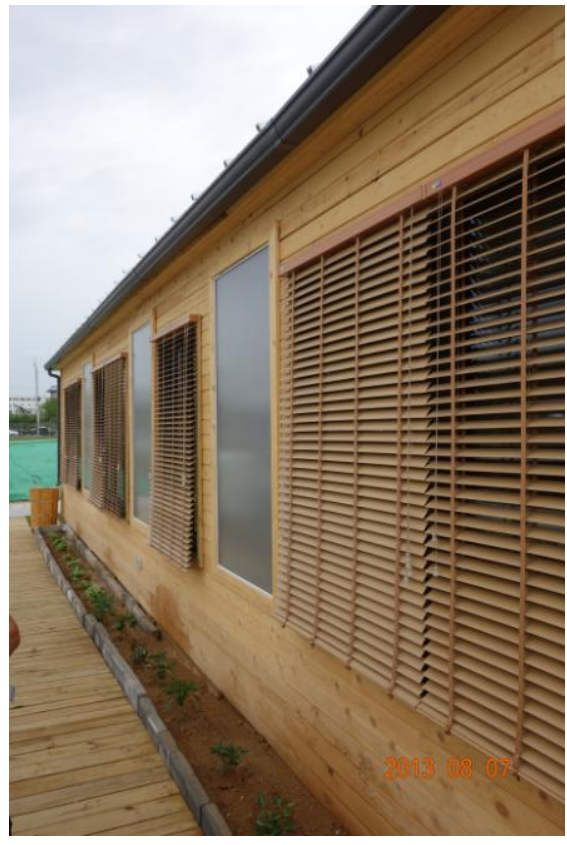

Figure 1. Outside sun louver in "Nexus House"

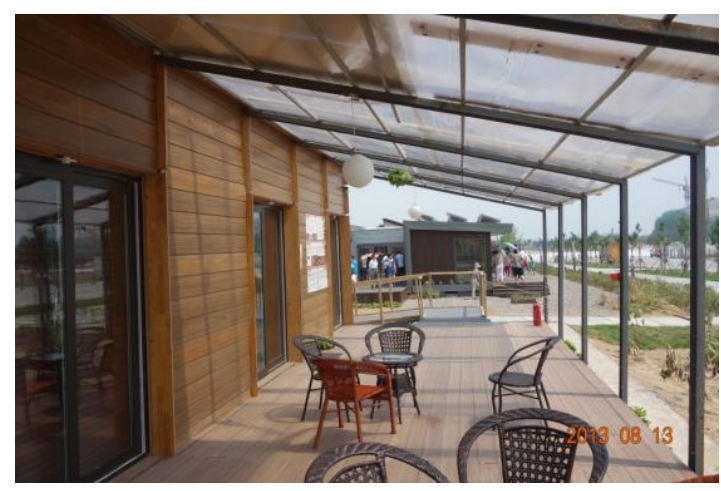

Figure 2. The south loggia in "Qi Ju"

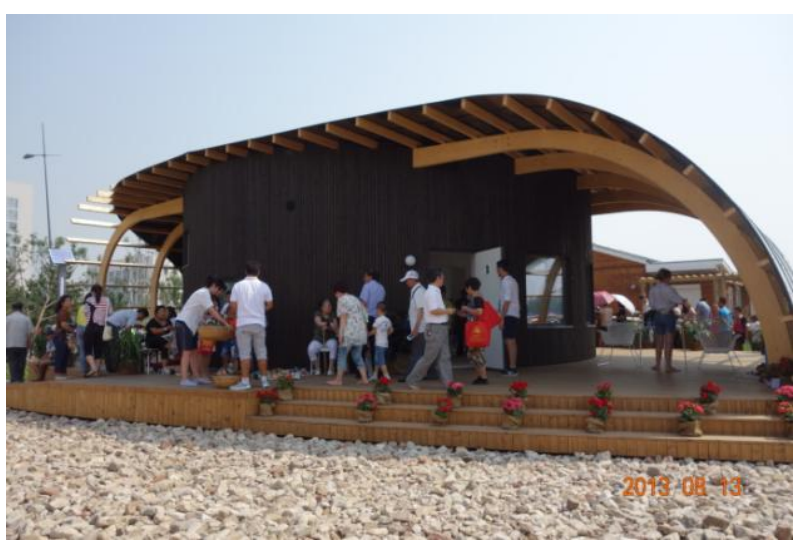

Figure 3. Chalmers University of Technology's house "HALO" 


\section{NATURAL Ventilation DESign}

Natural ventilation mainly includes two types: heat and wind pressure ventilation. When the climate outdoors is comfortable, natural ventilation can provide fresh air and take away the heat indoor improving thermal comfort conditions indoor. The design of wind pressure ventilation should design the openings of interior doors and windows reasonably on the basis of predominant wind direction in the construction site to let the wind flow smoothly and not be blocked indoor becoming cross ventilation. On the other hand, heat pressure ventilation creates indoor temperature difference artificially to guide airflows using the principle that density difference of hot and cold air can cause cross ventilation.

\section{A. Regulation of Natural Ventilation through Openings of Building}

Regulate indoor ventilation through doors, windows, skylights and other openings of building is the basic approach for the design of wind pressure ventilation. The house "Green Sun" made by Inner Mongolian University of Technology in SDC2013 takes advantage of mongolian yurt's structure. Roof structure of "Green Sun" extends to the ground reducing the wind stress area in the vertical direction effectively and guiding airflows. Double roofs provides the functions of residential heat preservation and heat insulation with the air layer between two roof adjusting temperature and air flow. The building roof is set as skylight that can be opened, which will form good ventilation under the action of wind and heat pressure indoor. (Fig.4)

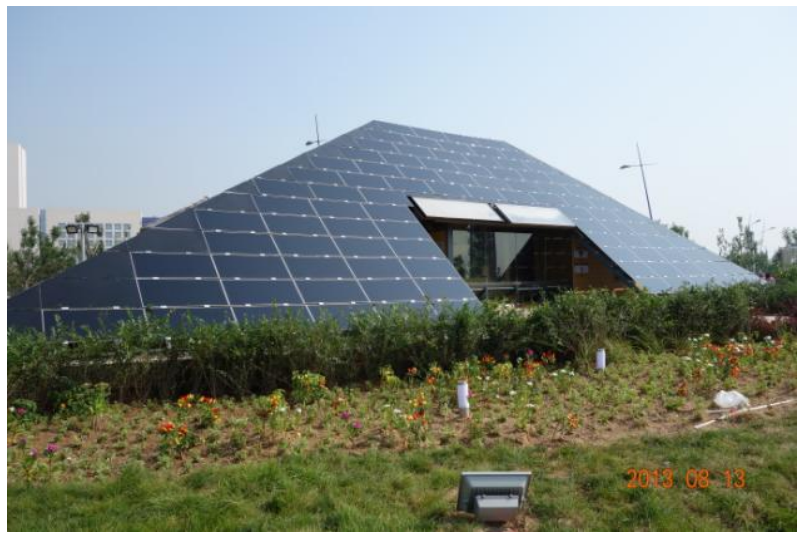

Figure 4. Inner Mongol University of Technology's house "Green Sun"

The computer simulations of wind environment method CFD are commonly used among teams in SD to assist the design in a windy environment. For example, Xiamen University uses the software Phoenics to simulate and optimize the design of natural ventilation. The T-shape courtyard of "Sunny Inside" connects four separated room spaces, providing a way of natural ventilation, which makes every room get good effect of natural ventilation. Moreover, The T-shaped courtyard is cut-through from east to west, the same as the local dominant wind direction of Datong city, which can form cross ventilation. A power sunroof is set at the centre junction of The T-shape courtyard to guide air flow up to outdoor.

\section{B. Roof Ventilation}

Ventilation layer is set in the building roof to let natural ventilation take away solar radiation heat that the roof has absorbed, which is an effective design strategy of building thermal isolation. Roof ventilation mainly includes ventilated attic, double off-contact roof.

Shanghai Jiaotong University's house "River Sunvelop" in SDC2013 uses ventilated ceiling. The space above the ceiling indoor is connected to the outdoor space and PCMs are used for thermal storage. On a hot day, the cooling system can guide the surrounding airflow around the roof to reduce the indoor-outdoor heat exchange, and thus lower the indoor temperature; on a cold day, a heat storage system in the roof can warm up the indoor area. So, loft space has the function of regulating indoor thermal environment.

\section{Air Deflector}

Air deflector is one of the methods that building components use to control natural ventilation, which guilds the airflow surrounding the building to regulate ventilation effect. The united team of Abbaspour University of Technology from Iran and Shanghai University of Engineering Science from China sets air deflector in veranda in their house "Shāremān". 24 plane wing shaped fins are used to steer current in the air deflector. The shape of the fins has been designed by fluid mechanics to reduce wind resistance avoiding eddy current. Air deflectors that can be driven by motor to rotate around the central axis and can be controlled with orientation by intelligent control system are set around the house with separation distance as $2.25 \mathrm{~m}$. When the system is working, control system can control the air deflector to let wind outdoor go through the building more smoothly according to the direction and speed of wind outdoor. Moreover, they absorb the design experience of a building component called "Baadgir" which is common used in traditional architecture in Iran setting 19 vent valves under the indoor ceiling which can control air flows promoting indoor natural ventilation according to the change of air pressure inside and outside. (Fig.6)

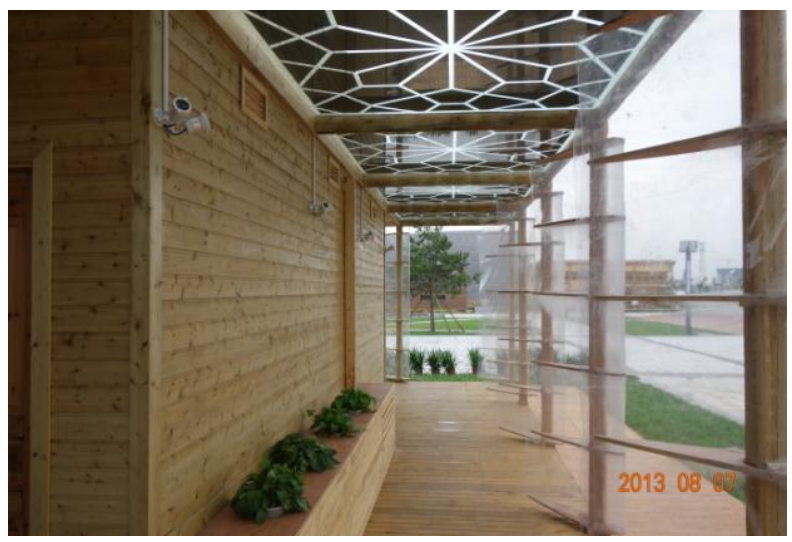

Figure 5. Ceiling ventilation in "River Sunvelop" 


\section{Ventlight}

The ventlight in Israel's house "Living Patio" in SDC2013 has a special window structure which adopts a new type window frame that can overturn and rotate around the central axis $180^{\circ}$. The casement is assembled by two different layers of glass: Ordinary insulating glass is used for thermal insulation; Dark glass is used to adjust the sunshine which is smaller with ventilation openings on both sides of the top and bottom. Ventilated cavity is in the middle of the two glass layers. With the change of season window frame can be rotate. In summer dark glass can be the outside one to absorb heat producing upward air flow in cavity to be discharged with the heat sunshine through ventilation openings which is like a external respiration type glass curtain wall; In winter dark glass is set inside to guide indoor air flow into cavity and send back through upper outlet after being heated which is like a Trombe wall playing the role of the heating of indoor air.

\section{Heat Accumulation Design}

Heat accumulation design has important significance to the design of competition building energy saving. For the sake of the convenience of disassembly and transportation, houses in SD are mainly made of light materials which make the heat stability of building not so good that the houses can't withstand the impact of outdoor periodic thermal fluctuations in summer very well. This needs to be considered in passive design that how to improve heat stability of building and how to store heat for flexible use according to the change of weather outdoor.

\section{A. Heat Accumulation by Heavy Materials}

It is called sensible heat accumulation that use large heat capacity materials like concrete, soil and water for heat accumulation in building. Virginia Tech University paves concrete slabs on the floor in their house in SDA2009 to improve thermal inertia of the building. New Zealand's house "First Light" in SDA2011 has a huge concrete table in the middle of the house for heat accumulation. The table is under a big glass roof which had inside abat vent to regulate the sunshine. And a stone wall is also put in the south entrance of courtyard of Xiamen University's house "Sunny Inside" which is paved with natural travertine for the accumulation of heat to enhance the heat stability of courtyard and plays a role of screen wall in Chinese traditional dwellings at the same time.

An example of heat storage by water could be seen in Pennsylvania State University's house in SDA2007. They use Glass bottles of water to built a water wall for heat accumulation (Fig.7); University of Arizona's house in SDA2009 use a water wall as Trombe wall which is built by waste plastic bottles. It can be used for accumulation of heat during the day and heat preservation at night. (Fig.8)

\section{B. Heat Accumulation by Phase Change Material}

The principle of heat accumulation by phase change material is latent heat thermal energy storage. The amount of latent heat in the phase change process of phase change material is very large and the phase change process can be nearly regarded as a process of isothermal [4]. Compared with the ordinary building heat storage materials, phase change materials have advantages of lighter, larger heat storage capacity and temperature remaining constant in the process of heat accumulation and release [5]. The applications of phase change materials in buildings can be divided into two parts: passive application and active application [6]. Passive application often uses phase change material as one layer or a part of building envelope making use of its good heat storage capacity to enhance building thermal stability or to store heat for flexible use by passive ventilation.
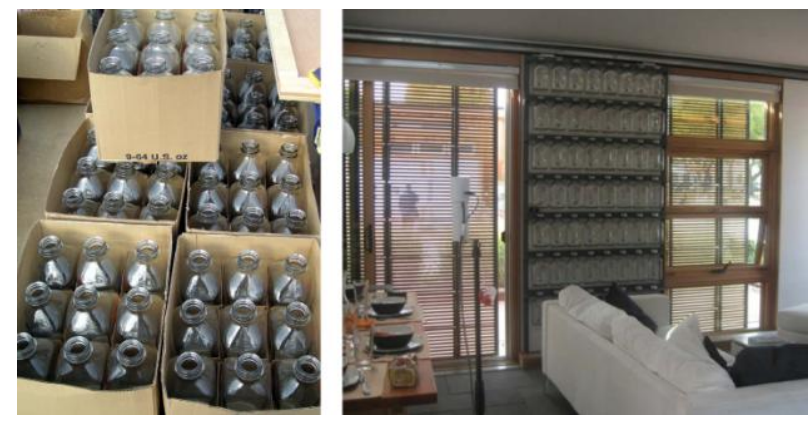

Figure 6. Ceiling ventilation in "River Sunvelop"

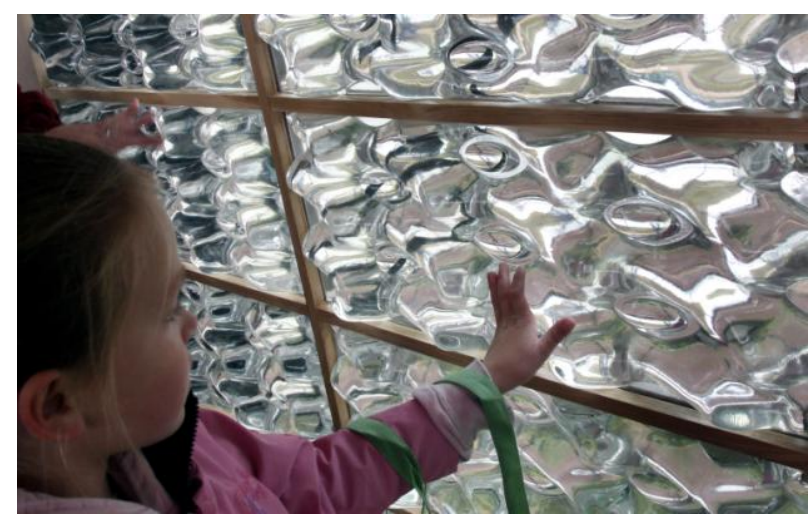

Figure 7. Water wall made of waste plastic bottles by University of Arizona in SDA2009

For example, Tongji University's house "Y-House" in SDE2011 installs a new thermal pressure ventilation system. The whole architecture is joints together to be a "Y" by 6 containers with a small room which has a glass roof in the middle of the house as a space to collect heat. Phase change material whose phase transition temperature is $50^{\circ} \mathrm{C}$ is put in the small room as heat storage material. In sunny daytime room temperature can be maintained around $50^{\circ} \mathrm{C}$ which is a large temperature difference compared with indoor temperature which is around $20^{\circ} \mathrm{C}$. The hot air goes up to outdoor through external opening on the top of room driving indoor air into this room through internal opening to form thermal pressure ventilation; at night phase change materials can release heat continuously to maintain temperature in the room to keep the thermal pressure ventilation. In spring and autumn it can not only save energy but also supply fresh air to use this system in order to get thermal comfort using 
natural conditions. In winter we can close the external opening to let the small room be a sunlight room to heat indoor air and reduce the energy consumption of heating. In summer the internal opening can be closed in case of the hot room affecting indoor refrigeration. (Fig.9)

Phase change material has been so widely used in SD that many houses in each competition have used it for different applications. The application of phase change material in SDC2013 is shown in Table I.

\section{EVAPORATIVE REFRIGERATION}

Evaporative refrigeration can lower the temperature in the local area and regulate thermal environment which is a common strategy of passive Design. Spray cooling system has been set in the out-porch of "Sunny Inside" which can spry mist for cooling improvement of the thermal environment under eave outdoor. It is mainly used for the cooling of tourists queue who are waiting for visiting the house.

In addition to the water spray cooling, plants are also the commonly used method to regulate building thermal environment. For example, South China University of Technology's house "E-Concave" has an organic farm around the building which adopts modular form of planting improving surrounding thermal environment and reflecting the ecology residential conception.

\section{BUFFER SPACE}

Cushion space is a synthesis passive building design strategy which is on the basis of thermal environment regulation strategy. When designing a building, transition space can be the container for climate control according to the different connections of architecture space, which is used to regulate thermal environment of the main building inter space.

Xiamen University's T-shape courtyard is integration of sunshade, thermal pressure ventilation, natural ventilation, sunlight room and other designs, because of that, it can regulate the indoor heat and humidity environment according to the change of outdoor climate conditions. The skylight glass is XIR laminated glass which can reflect $99 \%$

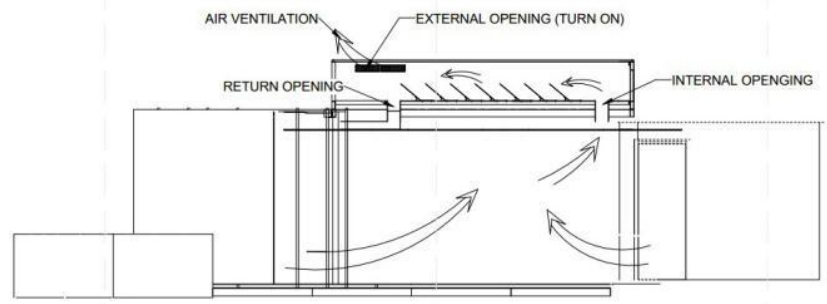

RUNING TACTICS IN AUTUMN OR SPRING infrared ray. So the courtyard will not be overheated under solar radiation and the openings of doors, windows, and skylight design well to have good ventilation. People can open doors, windows and skylight when outdoor climate is comfortable to make effective use of natural ventilation; Intelligent control system in the house can control all the equipments in the house according to the change of outdoor weather closing the outside shade curtain of skylight when solar radiation is too strong; courtyard becomes a sunlight room in winter as a result of greenhouse effect and regulate the thermal environment of rooms near indirectly. (Fig.10)

TABLE I. APPLICATIONS OF PHASE CHANGE MATERIAL IN SDC2013

\begin{tabular}{|c|c|c|}
\hline Team & \begin{tabular}{|c|} 
The application of \\
phase change materials
\end{tabular} & Application form \\
\hline $\begin{array}{l}\text { Wollongong University } \\
\text { "Illawarra Flame House" }\end{array}$ & $\begin{array}{c}\text { Set ventilation system on } \\
\text { the roof to cool PV } \\
\text { panels, phase change } \\
\text { materials are used to } \\
\text { store the collected heat. }\end{array}$ & Active \\
\hline $\begin{array}{c}\text { Xiamen } \\
\text { University"Sunny } \\
\text { Inside" }\end{array}$ & $\begin{array}{c}\text { Set the phase change } \\
\text { ventilation system under } \\
\text { the floor of courtyard } \\
\text { and on the ceiling of } \\
\text { living room. }\end{array}$ & Active \\
\hline Israel "Living Patio" & \begin{tabular}{|} 
Phase change materials \\
are used to store \\
refrigeration in the \\
radiation cooling system \\
at night.
\end{tabular} & Active \\
\hline $\begin{array}{l}\text { Xi'an University of } \\
\text { Architecture and } \\
\text { Technology "Qi Ju" }\end{array}$ & $\begin{array}{c}\text { Phase change materials } \\
\text { are sealed by plastic pipe } \\
\text { and placed in the south } \\
\text { wall. }\end{array}$ & Passive \\
\hline $\begin{array}{l}\text { BE-MA-NY } \\
\text { "Solatrium" }\end{array}$ & \begin{tabular}{|} 
Phase change materials \\
are put into floor tile and \\
placed under the floor.
\end{tabular} & Passive \\
\hline $\begin{array}{l}\text { Shanghai Jiaotong } \\
\text { University "River } \\
\text { Sunvelop" } \\
\end{array}$ & \begin{tabular}{|c|} 
Phase change materials \\
are used for heat storage \\
in ceiling ventilation.
\end{tabular} & Passive \\
\hline $\begin{array}{l}\text { Beijing university, the } \\
\text { university of Illinois at } \\
\text { urbana-champaign, } \\
\text { united "Etho House" }\end{array}$ & $\begin{array}{l}\text { Phase change materials } \\
\text { are installed inside the } \\
\text { wall. }\end{array}$ & Passive \\
\hline
\end{tabular}

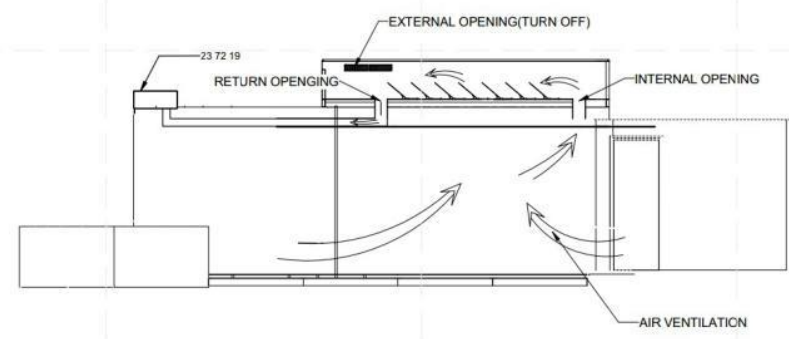

RUNING TACTICS IN WINTER

Figure 8. (a) Running mode in spring and autumn; (b) Running mode in winter 


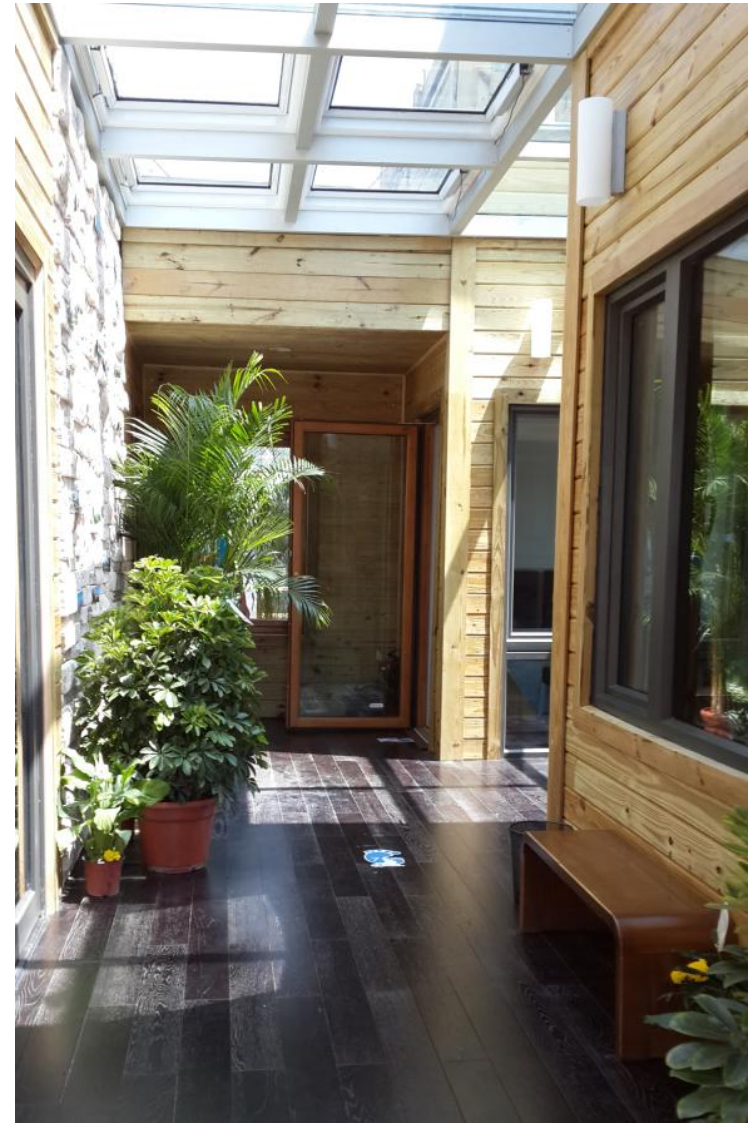

Figure 9. T-shape courtyard in "Sunny Inside"

There is a small courtyard in South China University of Technology's house "E-Concave". The glass door will be open in summer for ventilation and circulating water whose evaporation can drive the ventilation and the water absorption of heat is imported into the courtyard bringing natural cool into the house; In winter the glass door will be closed and water be drained. The courtyard becomes a sunlight room which can fully absorb sunlight to keep the indoors warm. In this way, the control of natural passive room temperature can be realized to keep warm in winter and cool in summer to save energy.

Sunlight room can be regarded as a design of weather buffer space which mainly uses thermal storage and thermal pressure ventilation to regulate thermal environment. As seen in Inner Mongol University of Technology's house "Green Sun" in SDC2013, a small sunlight room is set out of the south wall with plants and pebbles in it to store heat. Indoor windows are open to the sunlight room with sunshade outside. On a winter day sunlight room stores the heat that can be used at night, and on a summer day vent light in the sunlight room will be open to take away the heat inside by thermal pressure ventilation.

\section{CONCLUSION}

The international solar decathlon provides a large show platform for various new strategy of building thermal environment regulation. The feasibility and practicability of various thermal environment regulation strategies can be inspected in SD through testing of temperature and humidity and judges evaluation, feasibility. The practicality of various thermal environment control strategies has been tested. Looking at these participating buildings good design strategies are in the works according to the climate change target-regulations, reflecting the architectural adaptation to climate, naturally.

For green building, passive strategy should be used at first in the regulation of building thermal environment. And make the most use of natural conditions to improve local thermal environment eliminating its harmful influence when the weather outside is comfortable to keep comfortable indoor and reduce the working time of active devices; When passive measures are not actively efficient enough the system can be used to meet the requirements of indoor thermal environment combined with passive measures to reduce energy consumption; With the progress in technology intelligent control system can be used to monitoring climate parameters indoors and outdoors and target control and optimize the working performance of all the equipments indoor which integrates all kinds of technical strategies reasonably according to the different applicability to achieve the goal of energy-saving firmly.

\section{ACKNOWLEDGMENTS}

The research was supported by the National Natural Science Foundation of China (Grant No.51308481), and the Fundamental Research Funds for Central Universities (Grant No.20720150102).

\section{REFERENCES}

[1] http://www.sdchina.org. SD China official web.

[2] Peng, C., Huang, L., \& Huang, J. L. Y. (2015). Design and practical application of an innovative net-zero energy house with integrated photovoltaics: a case study from solar decathlon china 2013. Architectural Science Review, 58(2), pp.144-161.

[3] Umberto Berardi, Taoning Wang. (2014) Daylighting in an atriumtype high performance house. Building and Environment, 76(6), pp.92-104.

[4] Lin, W., Ma, Z., Sohel, M. I., \& Cooper, P. (2014). Development and evaluation of a ceiling ventilation system enhanced by solar photovoltaic thermal collectors and phase change materials. Energy Conversion \& Management, 88, pp.218-230.

[5] E. Rodriguez-Ubinas, L. Ruiz-Valero, S. Vega, et al. Applications of Phase Change Material in highly energy-efficient houses [J]. Energy and Buildings, vol 50, Feb. 2012, pp.49-62.

[6] Rodriguez-Ubinas, E., Ruiz-Valero, L., Vega, Sergio. and Neila, J. (2012) Applications of Phase Change Material in Highly EnergyEfficient Houses. Energy and Buildings, 50 (7), pp.49-62. 